\title{
Pedro de Ribadeneyra's Vida del P. Ignacio de Loyola (1583) and Literary Culture in Early Modern Spain
}

\author{
Rady Roldán-Figueroa
}

On June 23, 1584, Fray Luis de Granada (1504-88) wrote a letter to his friend, Pedro de Ribadeneyra (1526-1611), exalting the latter's literary qualities, including the candor of his prose. ${ }^{1}$ Writing from Lisbon, the prolific Dominican was moved to write in a spirit of gratitude and admiration after reading Ribadeneyra's Vida del P. Ignacio de Loyola, fundador de la Compañía de Jesus (1583). ${ }^{2}$ In the letter, he expressed the deepest admiration for Ribadeneyra's style and clarity. He also commended his Jesuit counterpart for his balanced account of the origins of the Society of Jesus as well as for his evenhandedness in praising the other religious orders. "May the Lord be blessed," Fray Luis exclaimed, "for he guided you in this path, in such an unbending trail, that without envy you praise your order, and without grumbling you magnify the others." He was clearly impressed by Ribadeneyra's ability to demonstrate the uniqueness and distinctiveness of the Society, without casting stones on the other institutes. As he stated:

To all my friends, without fear of recrimination, I have indicated what I feel about this book, and the fact is that I have not seen to date in our language a work written with such prudence and pronounced eloquence, as well as singular display of spirit and doctrine in history, not to mention the sobriety with which it praises its institute, without prejudice to other religious orders; instead, with great words of praise towards all of them,

1 For a cursory discussion of the relation between Fray Luis de Granada and Pedro de Ribadeneyra see Álvaro Huerga, Fray Luis de Granada: Una vida al servicio de la Iglesia (Madrid: Biblioteca de Autores Cristianos, 1988), 282-83, 288-89.

2 Pedro Ribadeneyra, Vida del P. Ignacio de Loyola, fundador de la religión de la Compañía de Jesús. Escripta en latín por el Padre Pedro de Ribadeneyra de la misma Compañía y aora nuevamente traduzida en romance, y añadida por el mismo autor. Dirigida al illustre y reverendiss. señor don Gaspar de Quiroga, cardenal y arçobispo de Toledo, inquisidor general, etc. (Madrid: Alonso Gómez Impresor de su Majestad, 1583). I am following the spelling and grammar as found in sixteenth- and seventeenth-century sources with minimal modifications.

(C) RADY ROLDÁN-FIGUEROA, 2016 | DOI 10.1163/9789004313354_010

This is an open access chapter distributed under the terms of the Creative Commons Attribution- 
and even more circumspect and conclusive reasons to defend and approve his own [...] more than in any of those that in these or similar matters are written. ${ }^{3}$

Fray Luis expressed similar feelings of high regard and praise in a second letter, dated July $28,1584 .{ }^{4}$ He exchanged these letters with Ribadeneyra just four years before his death in 1588 . The octogenarian was a well-known and wellestablished author whose devotional works circulated widely in Spain and the rest of Europe. ${ }^{5}$ The value of Fray Luis's personal endorsement did not go unnoticed. In 1586, María Ruiz (fl. 1584-95) published a second revised and expanded edition of Ribadeneyra's Vida. ${ }^{6}$ She was the widow of Alonso Gómez (fl. 158os), printer to the king and the publisher of the 1583 Spanish work. Either she or her late husband placed these letters in the opening pages of the 1586 edition. In an anonymous prefatory note, the publisher explained the decision to reproduce Fray Luis's letters without Ribadeneyra's consent. ${ }^{7}$ The publisher resolved to do so on account of the Dominican's fame and literary repute. "It has occurred to me," the publisher wrote in the note, "to place them here in

3 Luis de Granada, "Carta del padre Fray Luis de Granada, para el Padre Pedro de Ribadeneyra, de la Compañía de Jesús," in Pedro Ribadeneyra, Vida del Padre Ignacio de Loyola, fundador de la religión de la Compañía de Jesús (Madrid: Por la Viuda de Alonso Gómez, 1586), no pagination.

4 Luis de Granada, "Capítulo de otra del mismo padre, respondiéndole a una del Padre Ribadeneyra," in Ribadeneyra, Vida del Padre Ignacio de Loyola (1586), no pagination.

5 Keith Whinnom, "The Problem of the Best-seller in Spanish Golden Age Literature," Bulletin of Hispanic Studies 57 (1980): 189-98; Elizabeth Rhodes, "El Libro de la oración como el "best seller' del Siglo de Oro," in Actas del x Congreso de la Asociación Internacional de Hispanistas, Barcelona 21-26 de agosto de 1989, ed. Antonio Vilanova (Barcelona: Promociones y Publicaciones Universitarias, 1992), 525-32.

6 The 1586 printing was the second edition of the Spanish version. A second printing of the first edition, without revisions or additions, was made in 1584. See Pedro Ribadeneyra, Vida del Padre Ignacio de Loyola, fundador de la religión de la Compañía de Jesús. Escripta primeramente en latín por el Padre Pedro de Ribadeneyra de la misma Compañía, y aora nuevamente traduzida en romance, y añadida por el mismo autor (Madrid: Por la Viuda de Alonso Gómez, 1584). The 1586 edition, on the other hand, incorporated revisions and rewritings of the 1583 edition as well as the addition of new material.

7 María Ruiz, "El impressor al lector," in Ribadeneyra, Vida del Padre Ignacio de Loyola (1586), no pagination. The publisher's, or printer's, note appears unsigned. However, it clearly claims to be of the publisher's authorship. María Ruiz ran her late husband's print shop from 1584 to 1595. See Lourdes Gutiérrez, Purificación Lafuente, and Laura Carrillo, Mujeres impresoras (Madrid: Servicio de Información Bibliográfica, Departamento de Referencia, Biblioteca Nacional de España, 2014), 4-5. 
order to make the Christian reader aware of what this excellent man, so well known and beloved around the world for his holy life and admirable doctrine, feels about this present work." 8

Fray Luis de Granada's letters give us a good sense of the importance of the 1583 Vida, the Spanish translation of the author's Vita Ignatii Loiolae..$^{9}$ It intimates that Ribadeneyra's learned contemporaries welcomed his book. Moreover, the 1583 work was not simply a translation but in reality was a new composition. It was prepared with a new context in mind and in order to address different needs; needs that Ribadeneyra did not find as pressing in Italy where he composed the first Latin version. The 1583 Vida calls for special attention as Ribadeneyra's attempt to explain de novo the mission of the Society of Jesus to a complex and multilayered Spanish audience.

Ribadeneyra achieved considerable literary success after the publication of the 1583 Vida. Moreover, he earned the admiration of many to the extent that he was favorably compared to Fray Luis de Granada. Writing about Ribadeneyra's life, Cristóbal López (fl. 1611)—his companion of thirty-three years-reported that some "praised the accuracy of his writings as well as the good quality of his style, and they claimed that his was better than Fray Luis de Granada's." ${ }^{10}$ Ribadeneyra's Vida not only marked the beginning of his literary career as a Spanish author writing in the vernacular but also the beginning of an unequalled period in Spanish literature in which Jesuit voices contributed

8 Ruiz, "El impressor al lector," in Ribadeneyra, Vida del Padre Ignacio de Loyola (1586), no pagination.

9 Pedro Ribadeneyra, Vita Ignatii Loiolae, Societatis Iesu fundatoris, libris quinque comprehensa (Naples: no publisher, 1572). The Jesuit scholar Cándido de Dalmases dealt with the claims of Jean Marie Prat in Histoire du Père Ribadeneyra, disciple de saint Ignace (Paris: Victor Palme, 1862), 496-97, to the effect that Ribadeneyra first wrote a Spanish version and then translated the work to Latin in order to produce the first published Latin Vita. In response, Dalmases maintained that this is an error and that Ribadeneyra first wrote the original work in Latin, and that there is no evidence to the contrary. Cándido de Dalmases, ed., Fontes narrativi de S. Ignacio de Loyola et de Societatis Iesu initiis: Vol. II. Narrationes scriptae annis 1557-1574, MHSI 73 (Rome: Monumenta Historica Societatis Iesu, 1951), 19n14. Dalmases based his argument on Enrique del Portillo, "El original manuscrito de la primera edición castellana de la vida de N.P. San Ignacio, por el P. Rivadeneira," Razón yfe 42 (1915): 289-98.

10 Cristóbal López, Vida del p. P. de Ribadeneyra, religioso de la Compañía de Jesús, escrita por el mismo p. al modo de las Confesiones de s. Aug., añadida por su compañero que lo fué treinta y tres años el her [mano] Xpoual. López, en Madrid año de 1612, in Patris Petri de Ribadeneyra, Societatis Jesu sacerdotis, Confessiones, epistolae aliaque scripta inedita, ex autographis, antiquissimis apographis et regestis deprompta, vol. 2: Ribadeneyra II, MHSI 60 (Madrid: La Editorial Ibérica, 1923), 429-88, here 444. 
decisively to the shaping of the Spanish literary landscape. The present essay explores Ribadeneyra's methodical approach as a hagiographer, his place in the emerging Catholic literary culture of late sixteenth-century Spain, and the immediate context of his 1583 Vida.

\section{Ribadeneyra as Interpreter of the Society of Jesus}

Ribadeneyra had almost unrivaled credentials to act as an interpreter of the identity and mission of the Society of Jesus. He was a privileged witness of the early years of the Society as someone who could not claim the place of one of the founders, but could claim to have been one of Ignatius's closest disciples. He was born to a judeoconverso family in Toledo, where he also spent his childhood and early adolescence. ${ }^{11}$ It was here that he met Alessandro Cardinal Farnese (1520-89), while the cardinal was attending the funeral ceremonies of the Holy Roman empress, Isabella of Portugal (1503-39). ${ }^{12} \mathrm{He}$ left for Rome at the service of the cardinal in May 1539, at the tender age of twelve. ${ }^{13}$ After fourteen months in the cardinal's service, and running into difficulties with his patron, he was forced to seek the aid of Ignatius, who was settled in Rome about that time. ${ }^{14}$

His experience at the service of Cardinal Farnese left a deep impression on young Ribadeneyra. In fact, it colored his encounter with Ignatius and the nascent Society of Jesus. The contrast he observed between the careless lifestyle of the cardinal's courtiers and the piety and devotion Ignatius fostered among his disciples was one that was to shape his understanding of the distinctiveness of the Society. It certainly informed his representation of the Society as he endeavored to interpret its character and mission to others. Later in life, in his Confessiones, Ribadeneyra made quite an explicit criticism of the cardinal's lax way of life as well as that of his courtiers. He claimed to have lived

11 Manuel Ruiz Jurado, “Ribadeneyra, Pedro de," $D H C J$, 4:3345-46; José Carlos Gómez-Menor Fuentes, "La progenie hebrea del Padre Pedro de Ribadeneyra S.I. (Hijo del jurado de Toledo Álvaro Husillo Ortíz de Cisneros)," Sefarad: Revista de estudios hebraicos y sefardies 36, no. 2 (1976): 307-32.

12 Pedro Ribadeneyra, Confessiones, in Patris Petri de Ribadeneyra, Societatis Jesu sacerdotis, Confessiones, epistolae aliaque scripta inedita, ex autographis, antiquissimis apographis et regestis deprompta, vol. 1: Ribadeneyra I, M HSI $5^{8}$ (Madrid: La Editorial Ibérica, 1920), 6, henceforth Confessiones. The first English translation of Ribadeneyra's autobiography is forthcoming from the Institute of Jesuit Sources at Boston College.

13 Ribadeneyra, Confessiones, $7,84$.

14 Ibid., 8. 
for fourteen months without regard for God and that he "walked the streets of Babylon with his associates, blinded and miserable."15 He also remarked that during his service to the cardinal he "drank of the bitter chalice and golden cup that others drank from."16 He continued praising God for delivering him from the "silt and quagmire of the court, so sticky and dangerous." It pleased God, however, to bring him to "his house, holy house, house and residence of your servants." He juxtaposed unholy Babylon with the band of faithful disciples that had gathered around Ignatius, those "who with new spirit and new fervor, despising and treading all worldly things," set out to "establish the holy and blessed religion of the Society of Jesus, for [God's] glory and benefit of the world." 17

Ribadeneyra had a distinguished trajectory as a member of the Society of Jesus. His association with the Society commenced as soon as he met Ignatius. Indeed, he joined the Society of Jesus on September 18, 1540, a few days before Pope Paul III (r.1534-49) approved the new institute (September 27, 1540).18 Ignatius took personal care of his religious formation, as he was barely fourteen at the time. Later in life, he often referred to himself as Ignatius's Benjamin. He spent a few months studying at Leuven and a little more in Rome. It was, however, at Saint Mary Magdalene in Padua that he received a robust humanist formation..$^{19}$ He was in Padua from 1545 to 1549, and then in August 1549 he went to Palermo where he served as a reader of rhetoric. ${ }^{20} \mathrm{He}$ was ordained to the priesthood on December 8, 1553, and became a professed Jesuit on November $3,1560 .{ }^{21} \mathrm{He}$ went on to serve the Society in several capacities, but all of them outside Spain. For instance, he was the provincial of Tuscany and Sicily and in 1565 became the superintendent of the Roman College. ${ }^{22}$ In fact, Ribadeneyra had spent a considerable part of his adult life in Italy before he returned to the Iberian Peninsula in $1574{ }^{23}$

In the beginning, he felt alienated in Spain. In the Confessiones, he noted how he regretted his return, leaving behind many friends, and after many years, meeting new people, even those of the Society who did not know him or had heard of his labors. It was, in his view, "humanly impossible not to have great

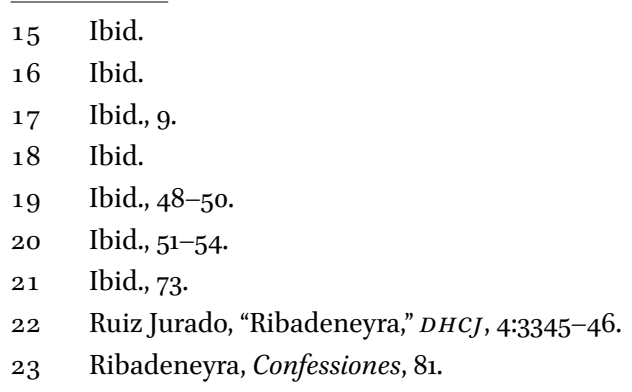


difficulty" in those circumstances. ${ }^{24}$ His own mother, whom he had not seen since he left with Cardinal Farnese in 1539, passed away in the same year of his return. ${ }^{25}$ Yet, it was here where he had a long literary career until his death at the age of eighty-five. He became the chief literary interpreter of the Society of Jesus of his generation. In the 1580 , he assumed in earnest the project of carving a niche among the Spanish literati. He used his literary labors to cultivate relations of patronage with well-positioned supporters of the Society. It was not just a matter of achieving literary fame, although he did accomplish this rather quickly. Instead, it was about the crystallization of a comprehensive vision that consisted of advancing the mission of the Society while furthering the consolidation of a national Catholic literary culture. He lauded God in the Confessiones for permitting him to accomplish that which he never foresaw and no one could ever have imagined; namely, that he, after so many years away from Spain, could have written as he did and been so well received by many. ${ }^{26}$

\section{Ribadeneyra and the Literary Mission of the Society of Jesus in the Vida (1583)}

Ribadeneyra's first major work was the Vita Ignatii, the earliest published biography of Ignatius of Loyola (1491-1556). ${ }^{27}$ Francisco de Borja (1510-72) commissioned him to write the biography. Although he was a fine Latinist, his literary production in Spanish was far more copious than in Latin. In this regard, he mirrored the main trend in Iberian religious writing, which was characterized at the time by a sharp turn to the vernacular. Indeed, eighty-eight percent of all works published in the Iberian Peninsula before 1601 were in Spanish. ${ }^{28}$ Moreover, Ribadeneyra's literary output has to be considered under the rubric of religious literature. Accordingly, it has to be interpreted as literature that was primarily produced from a very specific institutional location. He wrote as a Jesuit and with Jesuit interests in mind. He often wrote in the execution of specific tasks related to a particular office within the Society or in discharge of

\footnotetext{
24 Ibid., 83.

25 Ribadeneyra to Everard Mercurian, June 1, 1577, in Ribadeneyra 1:762-68, here 762; Cristóbal López, Vida del P.P. de Ribadeneyra, in Ribadeneyra 2:435.

26 Ribadeneyra, Confessiones, 84.

27 Pedro de Ribadeneyra, Vita Ignatii Loiolae (Naples, 1572).

28 Alexander S. Wilkinson, "Mapping the Print World of Early Modern Iberia," in Iberian Books: Books Published in Spanish or Portuguese or on the Iberian Peninsula before 1601, ed. Alexander S. Wilkinson (Leiden: Brill, 2010).
} 
a specific writing commission. Thus, as a religious writer, he performed a critical task for the Society; namely, he interpreted the character and distinctiveness of the still young religious institute for a readership that was made up of both clerical and lay readers. For religious writers such as Ribadeneyra, writing was conceived as mission; mission at the service of the religious institute, mission at the service of the church.

He pursued his literary endeavors with a clear awareness of the importance of writing for the future of the Society of Jesus. He articulated his views on this point in the 1583 Spanish edition of the Vida. The 1583 edition has to be treated as a different document on account of the numerous instances in which he rephrased the Latin original as well as the addition of substantial amounts of new material. It was in this work that he sought to re-introduce, so to speak, the figure of the founder of the Society to a broader readership, mainly constituted by lay members of the Spanish aristocracy. One of the new emphases was that of the literary mission of the Society. In 1583, Ribadeneyra offered his vision of a Society of Jesus actively involved, through its educational institutions and prolific writers, in the forging of a national Catholic literary culture.

Ribadeneyra dedicated the new Vida to Gaspar Cardinal de Quiroga y Vela (1512-94). The association with the cardinal marked an important turning point for the Society in Spain. The previous archbishop of Toledo, Juan Cardinal Martínez Silíceo (1486-57), had been a stern and persistent opponent of the Society. ${ }^{29} \mathrm{He}$ was especially notorious for his persecution of those Spanish Jesuits who-like Ribadeneyra himself-had a judeoconverso background. Quiroga, on the other hand, was a very close ally of the Society of Jesus. He developed intimate ties with the Society during his period of service to the Spanish crown in Italy, from 1555 to $1564 .^{30} \mathrm{He}$ befriended Ignatius of Loyola and had many encounters with him before he died. He also benefited greatly from his close association with the Jesuits. He formed part of a faction of the Spanish aristocracy that had close ties to Portugal. At the center of this faction was Joanna of Austria (1535-73), princess of Portugal, and the king's advisor Ruy Gómez de Silva (1516-73). ${ }^{31}$ Francisco de Borja was part of this political network and he also had an active hand in Quiroga's career. Hence, there was much to celebrate when, in 1577 , Quiroga was elevated to the see of Toledo as the successor of the ill-fated Bartolomé Carranza de Miranda (1503-76).

29 Isabella Ianuzzi, "Mentalidad inquisitorial y jesuitas: El enfrentamiento entre el Cardenal Silíceo y la Compañía de Jesús," Cuadernos de historia moderna 24 (2000): 11-31.

$30 \quad$ Henar Pizarro Llorente, Un gran patrón en la corte de Felipe II: Don Gaspar de Quiroga (Madrid: Universidad Pontificia Comillas, 2004), 49-95.

31 Ibid., 104. 
While Quiroga had been personally acquainted with Ignatius of Loyola, the audience that Ribadeneyra was aiming at had no access to a full account of the life of the cleric from Azpeitia. Hence, the Vida offered a unique opportunity to accomplish several vital purposes. First of all, it allowed Ribadeneyra to introduce the figure of Ignatius of Loyola as well as the spirit of the Society of Jesus to a complex audience, including his own Spanish Jesuit brethren. As his first major Spanish work, the Vida allowed him to address a need he had already identified and articulated in his correspondence of 1577 with Everard Mercurian (1514-80). In his view, the Society of Jesus was not well known (or not as well known as it should be) in Spain.

In his letter of June 1, 1577, he shared with Mercurian some deep impressions about the province of Andalusia. ${ }^{32} \mathrm{He}$ described the ethos of the province as one characterized by extreme rigor and strict observance. Such strict discipline was causing rifts between Andalusia and other provinces. As he pointed out: "From their greater observance of minute and exterior things, which seem to bloom in their province, some of them take their government to be holier, and more proper, and sincere, and in agreement with our institute, [...] taking the other provinces to be less observant, and to tell the word that I have heard, even 'conventuals."'33 According to him, some in the province followed a "strict spirit of mortification" inspired by the figure of Gonzalo González (fl. 1570s), who was known for his austerity. ${ }^{34}$ Although they took their discipline to be in line with the spirit of the Society of Jesus, it was causing more harm than good and it reflected their less than proper understanding of the Society's spirituality. Hence, since he had known Ignatius and was so experienced, some asked him to weigh in. "Thinking that I," he continued, "for having been brought up from childhood in the Society at the feet of our Father Ignatius, I could tell this in the true spirit, they asked me for my advice, but I did not say it but only to their superior, in whose presence I made an exhortation about this." ${ }^{35}$ Ribadeneyra was sensing important differences that would make him feel uncomfortable in Spain as time progressed.

32 Ribadeneyra to Everard Mercurian, June 1, 1577, in Ribadeneyra 1: 762-68.

33 'Di questa maggior osservanza di cose minute et steriori, che par' a loro fiorir' nella sua provincia, vengono alcuni a tener' per più santo il loro governo, et per più proprio, et sincero, et conforme al nostro instituto, et a far' poco conto degl'altri, tenendo quelli dell' altre provincie per meno osservanti, et per dir la parola ch'io ho inteso, per conventuali." Ribadeneyra 1:765.

34 Antonio Astrain, Historia de la Compañía de Jesús en la asistencia de España (Madrid: Razón y Fe, 1914), 2:457-58.

Ribadeneyra 1:765-66. 
In another letter, dated September 30, 1577, Ribadeneyra enunciated the main rationale for the writing and publishing program that he would pursue in the following decade. ${ }^{36}$ It is telling that in his letter Ribadeneyra was asking Mercurian if he could return to Rome. He had been in Spain for just under three years after his arrival in Barcelona in November 1574. Nevertheless, the tone of the letter indicates that despite his ill health he wanted to return to Rome as he felt underutilized in Spain and somewhat alienated from the other Spanish Jesuits. It is clear he preferred the situation in Rome and that he aspired to return there in order to better serve his institute.

In the letter, he listed reasons for staying in Spain as well as reasons for returning to Italy. Among the reasons for leaving Spain, he listed his desire to serve the Society either as an advisor or as a writer. "I can serve the Society," he declared, "either advising or writing some things related to the Society." He was well aware of his unique position in the Society as a close disciple of Ignatius, but at the same time twenty years younger than a towering figure such as Jerónimo Nadal (1507-80). He had both the experience and energy to assist Mercurian in some administrative capacity. He felt that in either case it would be better for him to be in Rome. That was especially true if he were to pursue writing, since, as he noted, that is where "all the documents from which any writing that will be gathered are found as well as the people with whom it can be discussed and corrected." 37

Moreover, he found that there was a considerable lack of knowledge in Spain and among Spanish Jesuits about the history of the Society. "I see new people, young, without experience in governance, raised by people of good will but lacking a proper understanding of our institute, absolutist in their authority, and with little regard, and who measure holiness - if I am not wrongwith a different measure from our Father Ignatius and reason calls for."38 Consequently, among the reasons for staying, he indicated that in Spain there were no older Jesuits with a broad and general experience of the affairs of the Society. Thus, he believed that he could, on account of his age and knowledge, help mitigate the situation. He even mentioned that he could address these needs by visiting all the colegios in the four Spanish provinces, lecturing on the ways and character of the Society of Jesus. ${ }^{39}$

His sense that there was a lack of understanding of the Society of Jesus in Spain ran very deep. In another letter he wrote to Mercurian, on October 7 ,

\footnotetext{
36 Ribadeneyra to Everard Mercurian, September 30, 1577, in ibid. $77^{8-84}$.

37 Ibid. 782 .

38 Ibid.

39 Ibid., $783-84$.
} 
1577, he revisited the subject but from a different angle. ${ }^{40}$ Here he argued that the Spanish court did not have a clear perception of the Society. He went further by suggesting that the Society had neglected the court in Madrid and that it lacked a robust presence there. He wrote: "The most important arena in the world, and where it is most beneficial that the Society shows what it is made of, after Rome, is the court of Philip II." ${ }^{41}$ He went on to remind the general that Madrid was the seat of every governing council of the Spanish monarchy, "a great machine and theater of the world." Nevertheless, he continued, "the Society does not have what is needed in place." ${ }^{42}$

In the end, of course, Ribadeneyra did not return to Italy. His friendship with Quiroga, a man who had also spent a considerable amount of time in Italy, must have alleviated some of his sense of alienation. Furthermore, Quiroga's elevation to the see of Toledo must have changed his perception of the situation in Spain. In any case, it should be clear that his letters of 1577 help explain how Ribadeneyra envisioned his future work as an interpreter of the Society of Jesus for the Spain of his day.

In fact, by October 8,1577 , he was already at work on a new project, the translation of the Vita. ${ }^{43}$ By the following year, he already had a full manuscript of the new Spanish Vida.$^{44}$ In a letter of January 8, 1582, to Ribadeneyra, Claudio Acquaviva (1543-1615) assured him that his new translation and the new additions would be welcomed by their brethren. ${ }^{45}$ Yet the manuscript had not been revised a year later. Finally, in his letter of January 3, 1583, Acquaviva informed him of the positive outcomes of the examination. ${ }^{46}$ In 1584 , after the publication of the new translation in 1583 , Acquaviva congratulated Ribadeneyra for his accomplishment. ${ }^{47}$

The book constituted a public display of the kind of political and ecclesiastical support that the Society enjoyed. Ribadeneyra was making a clear statement with his work. He was declaring to his Spanish audience that the once persecuted Society of Jesus, maligned by many as a "synagogue of Jews" and a hotbed of alumbrados, was now well established with a robust network of patrons within its reach. Moreover, he advanced the Ignatian vision of reform in manners and militant response to heresy by means of Catholic literacy.

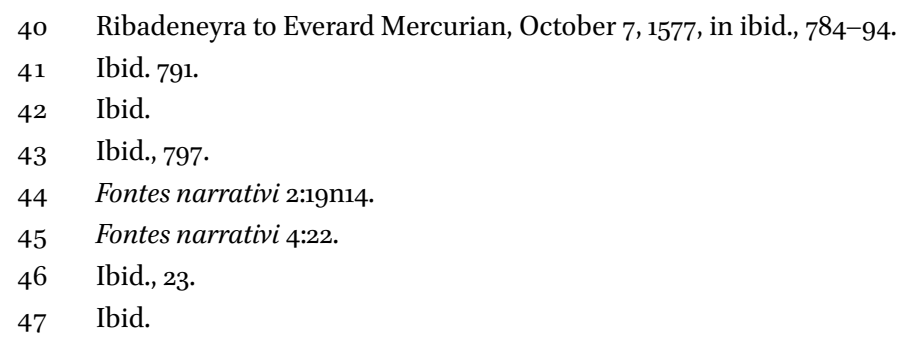


He inserted a new discourse on the importance of the colegios and their role in the crystallization of a Catholic literary culture. The section-found in book 3 , Chapter 22-was of crucial significance as it explained the overall educational vision of the Society and it is the best example of the kind of emphases he wanted to convey to his Spanish readership.

The opening lines introduced the central concern of the discourse. Ribadeneyra pointed out that the colegios were among the "principal ministries" of the Society and that Ignatius himself instituted them for the instruction of the young in "virtue and letters." However, there were some people of weight for whom the colegios appeared to be something "new," "indecent," and even "alien" to religious gravity. A special source of concern for these skeptics was the Society's involvement in elementary education through the foundation of grammar schools for children. "They ask," he pointed out, "the causes and motivations Ignatius had to institute these colegios and schools and to embrace with such care an occupation that on the one hand is so laborious and troublesome and on the other is so distant and not proper of the religious." 48

He dedicated the remainder of the chapter to answering the skeptics' objections. His answer was summarized in the origins of the Society. According to Ribadeneyra, the Society was instituted by God to fight heresy. Ignatius, he argued, saw that it was necessary to "raise children in the holy fear of God, and to teach them to be Christians from an early age." ${ }^{49}$ He elaborated this point extensively, drawing on the experience of the Society of Jesus throughout Europe, but especially in Germany. Catholic literacy was the solution for the Protestant challenge and the colegios were the instrument of the Society to spread it. The children the Jesuits were educating in them would become the new prelates and rulers; the canons, bishops, rectors, judges, and governors of the Christian commonwealth. ${ }^{50}$ Children were brought up to become leaders. ${ }^{51}$ He used an example drawn from John the Deacon's (d. before 882) Vita S. Gregorii papae (The life of St. Gregory, the pope) in which Pope Gregory the Great (r.590-604) was represented as teaching children to sing. "Can it be less important," he asked with derision, "to teach virtue and letters to children, with which they may become living temples of God and good rulers of the republic, than to teach them to sing?"52 For Ribadeneyra, this would be the great achievement of the colegios; namely, a robust Roman Catholic literary culture built from the ground up.

\footnotetext{
48 Pedro de Ribadeneyra, Vida del P. Ignacio (1583), 164r-164v.

49 Ibid., $165 \mathrm{v}$.

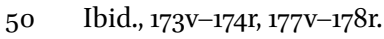

$51 \quad$ Ibid., $174 \mathrm{v}$.

52 Ibid., $176 \mathrm{v}-177 \mathrm{r}$.
} 


\section{Ribadeneyra and the Interlocking of Jesuit and Spanish Literary Cultures}

Ribadeneyra's literary career illustrates how writing took on a distinctive character for the Society of Jesus. As a Jesuit, he was able to align writing as a devotional practice with the fulfillment of paramount organizational objectives. The nascent religious foundation had pressing institutional needs, analogous to the needs of similar religious bodies. The Society of Jesus needed to recruit new members, train them properly, and secure the material resources that could ensure its perpetuation. Its fast expansion made these demands even more urgent. Writing, and especially writing that was meant for publication, facilitated the creation of a positive public opinion regarding the Society. It was in this sense that writing and publishing furthered the institutional aims of the Society of Jesus. Books could be used to attract new members, introduce them to the core tenets of the religious institute, provide the new recruits with ideal models of piety and loyalty, and enlist the patronage of wealthy admirers.

Yet, he also pursued writing as a spiritual practice. For instance, in his Confessiones he recorded the abiding motives that inspired him and guided him to write. Reflecting upon the writing of the Confessiones, he asked, "Why then, for what reason do I write about things that are long gone?" "I write," he responded, "in order to have memory of your gifts and to thank you for them, in order to confess my miseries before Your Reverence, and to cry for them, and to ask that you may forgive them."53 He saw writing as a way of serving God, and he was forever grateful to God for allowing him to offer such service. As he stated, he was grateful to God for "availing yourself of me in the books that by your will — as shown to me by your ministers and my superiors - I have written so far." ${ }^{54} \mathrm{He}$ wrote with two additional ends in mind: to build up the faithful and for the well-being of the Society of Jesus. ${ }^{55} \mathrm{He}$ conveyed a similar feeling in a letter of March 1, 1604, to Ana Manrique (d.1615), countess of Puñonrostro. Referring to his Manual de oraciones, he declared, "In the beginning, I wrote it in order to have some relief of my old age, and to ask the favor of the Lord through the intercession of his saints; I also wanted to make myself joyfully useful in something that could be of benefit." 56 On one occasion he called writing a "precise, grave, and continuous" occupation. ${ }^{57}$

\footnotetext{
53 Ribadeneyra, Confessiones, 89 .

54 Ibid., 84.

55 Ibid.

56 Ribadeneyra to Ana Manrique, March 4, 1604, in Obras escogidas del Padre Pedro de Rivadeneira de la Compañía de Jesús, ed. Vicente de la Fuente (Madrid: Biblioteca de Autores Españoles, 1952), 6o6-7.

57 Ribadeneyra, Obras escogidas, 601.
} 
He articulated an image for the Society of Jesus that was exceptionally useful for the advancement of important institutional ends. However, of equal or greater value was the lasting influence he had on the formation of two distinctive literary cultures. The primary literary culture he contributed to was that of the Society of Jesus itself. Here, he laid the foundations for a historiographical style of major consequence. Of great importance in this regard are his biographies of the first three generals of the Society: Ignatius of Loyola, Diego Laínez (1512-65), and Francisco de Borja. In his biographical works, he set a model and pattern that later Jesuit historians followed.

While the historiographical virtues of Ribadeneyra's work are often recognized, the Bollandists are the ones who customarily get noticed on account of their "modern" historiographical sensibilities. ${ }^{58}$ In 1910, the Belgian scholar Hippolyte Delehaye (1859-1941)—himself a Jesuit and a Bollandist—coined the term "hagiology" to describe a historical science, the foundation of which he attributed to the Jesuits Heribert Rosweyde (d.1629) and Jean Bolland $(1596-1665) \cdot{ }^{59} \mathrm{He}$ characterized their approach as "hagiographie scientifique"; a historiographical style that consisted of methodical source criticism, analysis of literary styles, and the study of local history. ${ }^{60}$ According to Delehaye, these were the tools that the hagiologist would use to discriminate between facts and myths found in the hagiographical remains. The Bollandists' ultimate aim was to distinguish what is "really historical" from what is nothing more than the invention of the "imagination of the pious writers." 61

Certainly, Delehaye's perspective was profoundly shaped by the historical positivism of Leopold von Ranke (1795-1886). ${ }^{62}$ Indeed, von Ranke emphasized

$5^{8}$ Among the scholars who have noted Ribadeneyra's novel hagiographical approach are Jodi Bilinkoff, "The Many 'Lives' of Pedro de Ribadeneyra," Renaissance Quarterly $5^{2}$ (1999): 180-96; Jonathan Edward Greenwood, "Readers, Sanctity, and History in Early Modern Spain: Pedro de Ribadeneyra, the Flos sanctorum, and Catholic Community" (MA thesis, Carleton University, 2011); Miguel Gotor, "Hagiografía y censura libraria: El quinto capítulo sobre los milagros de la Vida de Ignacio de Loyola de Pedro de Ribadeneyra entre corte de reyes y obediencia romana," in Los jesuitas: Religión, política y educación (siglos $X V I-X V I I I)$, ed. José Martínez Millán, Henar Pizarro Llorente, and Esther Jiménez Pablo, 3 vols. (Madrid: Universidad Pontificia Comillas, 2012), 2:1007-28.

59 Hippolyte Delehaye, "Hagiology," in The Encyclopedia Britannica, 11th ed., 29 vols. (New York: Encyclopedia Britannica, 1910-11), 12:816-17. See also Jan Machielsen, "Heretical Saints and Textual Discernment: The Polemical Origins of the Acta Sanctorum (16431940)" in Angels of Light? Sanctity and the Discernment of Spirits in the Early Modern Period, ed. Jan Machielsen and Clare Copeland (Leiden: Brill, 2013), 103-41.

6o $\quad$ Ibid., 817.

$61 \quad$ Ibid.

62 On von Ranke's historical positivism, see Elizabeth A. Clark, History, Theory, Text: Historians and the Linguistic Turn (Cambridge, MA: Harvard University Press, 2004), 9-12. 
the importance of "documentary research" (urkundliche Forschung), calling it the "historical principle" that distinguishes history from philosophy and theology. ${ }^{63} \mathrm{He}$ was convinced that the golden standard of historical inquiry is for it to be "documentary" (urkundlicher) and "exact" (genauer) research. ${ }^{64}$ From the standpoint of modern positivist historiography, therefore, historical inquiry into the facts was harnessed by the methods of the humanistic discipline of philology. ${ }^{65}$ Consequently, Delehaye designated the Bollandists' as practitioners of the "scientific" discipline of hagiology on account of their use of documentary sources.

Yet, if the stress on documentary sources was the hallmark of a new, modern style of hagiography, then Ribadeneyra has to be recognized as one of its earliest exponents. Moreover, if "the whole modern method of historical research is founded upon the distinction between original and derivative authorities," as the Italian historian Arnaldo Momigliano (1908-87) maintained, then Ribadeneyra was practicing a very novel brand of hagiography ${ }^{66}$ Indeed, in his hagiographical works he displayed an exceptional historical sensibility that set him apart from other Spanish hagiographers of the period. ${ }^{67}$ The historian and hispanist Jodi Bilinkoff (b.1955), who did not hesitate to treat Ribadeneyra as a "biographer" or as someone practicing "life-writing," rightly observed that his hagiographical writings defied conventional categories of genre and style. ${ }^{68}$

In the Vita (1572), he declared the core principles that would guide his hagiographical work for the next forty years. Among these, his disciplined approach to hagiography as such has to be highlighted. He described hagiography as "sanctorum vita referenda." ${ }^{69}$ That is, he saw himself as "reporting" or "relating" the lives of saints. In 1583 , he translated this phrase as "relatando vidas de

63 See Leopold von Ranke's "Idee der Universalhistorie," edited with introduction and notes in Eberhard Kessel, "Rankes Idee der Universalhistorie," Historische Zeitschrift 178, no. 2 (1954): 269-308, here 302.

64 "Man glaube nicht, daß dies der Freyheit der Betrachtung Eintrag thue; nein, je urkundlicher, genauer, ergiebiger die Forschung, desto freyer kann sich die Kunst bewegen." Kessel, "Rankes Idee der Universalhistorie," 298.

65 Robert Morstein-Marx, "Political History," in A Companion to Ancient History, ed. Andrew Erskine (Hoboken: Wiley-Blackwell, 2009), 99-111, here 102-4.

66 Arnaldo Momigliano, "Ancient History and the Antiquarian," Journal of the Warburg and Courtauld Institutes 13 (1950): 285-315, here 286.

67 In a short entry, Eusebio Rey called him the "creator of modern hagiography." Eusebio Rey, "Ribadeneyra, Pedro de," in Diccionario de la historia eclesiástica de España, ed. Quintín Aldea Vaquero et al., 4 vols. (Madrid: Instituto Enrique Flórez, Consejo Superior de Investigaciones Científicas, 1973), 3:2085.

68 Bilinkoff, "Many 'Lives' of Pedro de Ribadeneyra," 184.

69 Ribadeneyra, "Carissimis in Christo," in Vita Ignatii (1572), no pagination. 
santos." ${ }^{70} \mathrm{He}$ believed that the relating of the lives of saints was a form of historical writing that was subject to the highest standards. "Truth," he stated, "is the first law of history [historiae prima lex veritas est]." ${ }^{71}$ In the Spanish edition of 1583 , he reworked this statement significantly, strengthening the tenor of the work and clarifying his aspirations: "I hereby avow that I will not say things that are untrue and questionable, but instead those that are well known and well researched [muy sabidas $y$ averiguadas]. ${ }^{72}$ With this statement, Ribadeneyra claimed certain relative independence and even critical distance from tradition, subjecting traditional accounts and models of telling the lives of saints to scrutiny. He made this move without abandoning the moral and spiritual ends of hagiography, which would have amounted to forsaking the genre as a whole.

Furthermore, in 1572, Ribadeneyra was calling for a writing of saints' lives that was based on evidence of the first order, such as — and especially — eyewitness accounts. He was clearly conscious of the qualitative difference between types of sources. In his first hagiography, he claimed the privilege of having met Ignatius in person and having witnessed the very beginnings of the Society as a religious institute. However, he did not rely solely on his own experience to report the story of Ignatius and the Society of Jesus. He worked from written sources as well, especially the writings of Luis Gonçalves da Câmara (1519-75) and Diego Laínez. ${ }^{73}$

He collected other documents as he was writing the work, adjusting his progress to the availability of sources. Hence, in his letter to Jerónimo Nadal of October 24, 1567, he lamented his lack of progress due to his ill health. Yet, even if he wanted to speed up his work, he was not able to because he was lacking sufficient documentation. Juan Alfonso de Polanco (1517-76) was bringing together those manuscripts that were found in Rome and in other locations. ${ }^{74}$ He even noted that the third part of the Vita was on hold because it required

70 Ribadeneyra, "A los hermanos," in Vida del P. Ignacio de Loyola (1583), no pagination.

71 "Et quoniam historiae prima lex veritas est, hoc in primis profiteor, me nihil inexplorati scripturum: sed res mihi notas, certas, testatasque litteris proditurum.” Ribadeneyra, "Carissimis in Christo," in Vita Ignatii (1572), no pagination.

72 "Y porque la primera regla de la buena historia es, que se guarde verdad en ella: ante todas cosas protesto, que no dire aqui cosas inciertas y dudosas, sino muy sabidas, y averiguadas." Ribadeneyra, "A los hermanos," in Vida del P. Ignacio de Loyola (1583), no pagination.

73 Ribadeneyra, "Carissimis in Christo," in Vita Ignatii (1572), no pagination.

74 Pedro de Ribadeneyra to Jerónimo Nadal, October 24, 1567, in Epistolae P. Hieronimi Nadal Societatis Jesu, ab anno 1546 ad 1577, nunc primum editae et illustratae a patribus ejusdem Societatis (Madrid: Agustín Avrial, 1902), 3:538-40, here 539. 
extensive documentation that was at the time still to be collected. ${ }^{75} \mathrm{He}$ remained committed to the careful documentation of his accounts throughout his career. Typical of his approach was the comment he made in the preface to Vida del P. Francisco de Borja (1592). ${ }^{76}$ In view of a future book, he asked the late general's close associates to write everything they knew about him. He then gathered all these writings and collected other sources as well. ${ }^{77}$

The truly innovative, almost revolutionary, trait of his relatos was the independence and critical distance he took in relation to traditional forms of hagiography. Of course, this does not exclude the possibility that he could manipulate the narrative to his own ends. The point here, however, is how he regarded traditional hagiography. He was critical of the kind of embellishments that characterized traditional saints' lives. In the Vita (1572), he argued that the use of forgeries for the writing of saints' lives was more reproachable than the use of simple lies in daily life. ${ }^{78}$ The immediate application of this principle was the conviction that the story of Ignatius's exemplary life should not be overstated by adding fiction to the real facts. To the contrary, the growth and spread of the Society of Jesus was the work of God in unambiguous and manifest ways that could be corroborated with living witnesses. In the Spanish edition of 1583, he considerably amplified this passage, providing a bold statement of his hagiographical approach. He criticized and took distance from the customary representations of saints' lives, typically embellished after the arbitrary inclinations of their authors. "As if God needed forgeries," he remarked. He took his reservations a step further by denouncing the way that traditional lives of saints incorporated stories of fake miracles intended to aggrandize a saint's profile, "or as if it was not alien to Christian piety to want to honor and glorify the Lord, who is the ultimate and eternal truth, with contrived stories and miracles."79

75 Ribadeneyra to Jerónimo Nadal, October 24, 1567, in Epistolae P. Hieronimi Nadal 3:539.

76 Pedro Ribadeneyra, Vida del P. Francisco de Borja, que fue duque de Gandía, y después religioso y III general de la Compañía de Jesús (Madrid: P. Madrigal, 1592).

77 Ribadeneyra, "Al christiano lector," in Vida del P. Francisco de Borja, no pagination.

78 "Est enim persuasum nobis, cum in omni re mentiri, turpe esse, tum vero, in sanctorum vita referenda, turpissimum. Nam neque Deus, ad gloriam suam illustrandam, mendaciis nostris indiget: neque primam, et summam veritatem, falsis narrationibus, et commentiis honorare velle, fas est." Ribadeneyra, "Carissimis in Christo," in Vita Ignatii (1572), no pagination.

79 "Por parecerme, que aunque qualquiera mentira es fea y indigna de hombre Christiano, pero mucho mas la que se compusiesse, y forjasse relatando vidas de Santos. Como si Dios tuviesse necessidad della, o no fuesse cosa agena de la piedad christiana, querer honrar y glorificar al Señor, que es summa y eterna verdad, con cuentos y milagros fingidos." Ribadeneyra, “A los hermanos," in Vida del P. Ignacio de Loyola (1583), no pagination. 
His judicious objection to the paramount place bogus miracles had in traditional accounts of saints' lives could be seen as an indication of a potentially larger problem for him and the Society of Jesus. In the last chapter of Vita (1572), he addressed an important question related to Ignatius's holiness: "But some say, if these things are true, as certainly they are; what is the cause, why his holiness is less confirmed by miracles?"80 He proceeded to explain that miracles were in God's power and that they were God's doing. Nevertheless, it would appear that if there were no miracles associated with Ignatius, then his biographer would have to tone down their importance. The French historian Axelle Guillausseau explained Ribadeneyra's caution as a response to the tighter controls on canonization procedures imposed by the Council of Trent. ${ }^{81}$ While that may be true, his circumspection has to be seen more in terms of his methodical approach to writing than anything else. After all, the tighter regulations on canonization came about after 1572 under Popes Sixtus V (r.1585-90) and Urban VIII (r.1623-44), and especially the latter.

Moreover, his critical posture with regard to traditional accounts of saints' lives was also evident in his greatest and most important hagiographical work, the Flos sanctorum (1599). ${ }^{82} \mathrm{He}$ offered some rare but weighty insights about the art of writing saints' lives in his preface, "Al christiano y benigno lector." Ribadeneyra asserted that traditional saints' lives were filled with stories that he described as "obscure," "entangled," and "doubtful." Some stories in saints' lives were "on the one hand so apocryphal, and on the other so well accepted and deeply rooted in popular opinion that they can neither be approved without considerable affront to the truth, nor done away with without causing offense to the vulgar and common people." ${ }^{83}$ Some of these works incorporated that which resulted in "amazement instead of edification" and more "miracles instead of virtues." ${ }^{84} \mathrm{He}$ also announced an important principle for the use of his sources—chiefly Cesare Baronio's (1538-1607)

8o "Sed dicat aliquis, si haec vera sunt, ut profecto sunt; quid causae est, quamobrem illius sanctitas, minus est testata miraculis?" Ribadeneyra, Vita Ignatii (1572), 208r.

81 Axelle Guillausseau, "Los relatos de milagros de Ignacio de Loyola: Un ejemplo de la renovación de las prácticas hagiográficas del siglo XVI y principios del siglo XVII," Criticón 99 (2007): $5^{-56 .}$.

82 Pedro Ribadeneyra, Flos sanctorum, libro de las vidas de los santos, escrito por el Padre Pedro de Ribadeneyra, de la Compañía de Jesús, natural de Toledo. Dirigido a la reyna de España Doña Margarita de Austria, n.s. En el qual se contienen las vidas de Christo nuestro señor, y de su santissima madre; $y$ de todos los santos de que reza la Yglesia Romana, por todo el año (Madrid: Luis Sánchez, 1599).

83 Ribadeneyra, "Al christiano y benigno lector," in Flos sanctorum, no pagination.

84 Ibid. 
Annales ecclesiastici. ${ }^{85}$ He pledged to select those things that are "true and researched" and that can move the reader to the imitation of the saints themselves. Conversely, he also indicated he would leave out those things that "even if they are well received among the common people," did not appear to him to be sufficiently "well founded, and well authorized, that I may affirm them." 86

Ribadeneyra played an important part in the creation of a literary culture among the Jesuits in the Iberian Peninsula. As his works circulated and were read, his Jesuit emulators appropriated his literary style as well as his historiographical dexterity. They in turn contributed to the solidification of a literary body held together by the common objective of furthering the institutional mission of the Society of Jesus. Hence, the literary production of these Spanish Jesuits has to be treated with integrity as a consistent whole. Furthermore, he can be credited with beginning a hagiographical school that anticipated and, for a time, ran parallel to the Bollandists. This Spanish and Jesuit school of hagiography was active in the later decades of the sixteenth and first half of the seventeenth century. It included figures such as Martín de Roa (1559-1637) and Juan Eusebio Nieremberg (1595-1658). It is possible that the Colegio Imperial of Madrid, with which Nieremberg became so closely identified, provided an institutional home for this hagiographical effort. ${ }^{87}$ In any case, other Jesuits who occupied the office of procurador in the Madrilenian court could also be counted as part of this school. Such was the case with Luis de Guzmán (d.1605) and Luis Piñeiro (or Pinheiro, 1560-1620). These two were responsible for histories of Jesuit missionary work in the East that are grossly underestimated by modern scholars who fail to see the influence they had in the seventeenth century. If we take into consideration that Ribadeneyra's Vida was published in 1583 and that the Jesuit Juan de Mariana's (1536-1624) Historiae de rebus Hispaniae libri $x x \mathrm{v}$ appeared in 1592, one can begin to imagine the transcendence of Ribadeneyra's methodical considerations for Spanish Jesuit historiography 88

He also contributed to the creation of a national literary culture. In this regard, he formed part of a broader trend shaped by a plethora of religious writers who, like him, were turning to the vernacular in order to reach the laity

85 Ribadeneyra indicates that he used the edition printed in Rome, Cesare Baronio, Annales ecclesiastici, 12 vols. (Rome: Ex Typographia Vaticana, 1588-1607).

86 Ribadeneyra, "Al christiano y benigno lector," in Flos sanctorum, no pagination.

87 For more on the Colegio Imperial see José Simón Díaz, Historia del Colegio Imperial de Madrid (Madrid: Instituto de Estudios Madrileños, 1992). On Nieremberg, see D. Scott Hendrickson, Jesuit Polymath of Madrid: The Literary Enterprise of Juan Eusebio Nieremberg (1595-1658) (Leiden: Brill, 2015).

88 Juan de Mariana, Historiae de rebus Hispaniae librixxv (Toledo: Petri Roderici, 1592). 
with their works. Together, these religious writers-including figures such as Granada and Fray Luis de León (1527-91) - laid the foundation of Spain's Catholic literary culture. Their literary achievements dominated modern Spanish intellectual life with hegemonic force. Ribadeneyra practiced a spirituality of writing that combined a sense of duty towards the Society of Jesus with a profound love for God as well as the conviction that these could come together in writing. The same spirituality inspired numerous authors that were either Jesuits themselves or were educated in Jesuit schools, fulfilling in these ways the Jesuit vision of building a Catholic literary culture from the ground up. Among these were Pedro Pablo de Acevedo (1521-73), Juan Luis de la Cerda (1558-1643), Francisco Gómez de Quevedo y Villegas (1580-1645), Anastasio Pantaleón de Ribera (1600-29), Pedro Calderón de la Barca (1600-81), and Baltasar Gracián y Morales (1601-58). Interestingly, Ribadeneyra was very aware of the strategic importance of literacy as well as the urgency of producing a literature that conveyed the beliefs and values of Tridentine Christianity. He embraced the calling, in good Jesuit spirit, "ad maiorem Dei gloriam" (for the greater glory of God). 